\title{
Winemaking,
}

\section{Environmental Impacts and Sustainability: New Pathways from Vineyard to Glass? ${ }^{1}$}

Carla Pires Vieira da Rocha² \& Eunice Sueli Nodari ${ }^{3}$

\begin{abstract}
In this text we explore the relationship between vitiviniculture and environment, observing the current conjuncture in which environmental problems are worsening. Taking as a baseline a survey of the literature and as a time frame the 1970s to the present, we begin by examining the development of vitiviniculture from the wider perspective of the contemporary global agrifood system, highlighting in particular the environmental impacts generated by this system. Next, taking into account the panorama of vitiviniculture in Brazil, we turn our focus to notions of sustainability with the aim of outlining possibilities for a reconfiguring of this issue and, at the same time, contextualizing the extent to which the country has been pursuing this direction. We conclude that the future of winemaking depends especially on a more harmonious intervention of human beings in the environment.
\end{abstract}

Keywords: Winemaking; Global Agrifood System; Sustainability; Vitiviniculture.

\footnotetext{
${ }^{1}$ The present article was realized with the support of Brazil's Higer Education Personnel Development Agency(CAPES) - Funding Code 001 - and forms part of the project "From land to table: an environmental history of vitiviniculture in the Americas," which receives financial support from CNPq.

$2 \mathrm{PhD}$ in Human Sciences (Federal University of Santa Catarina - Brazil), ORCID: http://orcid.org/0000-0003-2457-4634, e-mail: carlapvrocha@gmail.

${ }^{3} \mathrm{PhD}$ in History at Pontifical Catholic University of Rio Grande do Sul - Brazil. Full Professor at the Federal University of Santa Catarina, Florianopolis, SC - Brazil, ORCID: https://orcid.org/0000-0001-5953-649X, eunice.nodari@ufsc.br
} 
$\Gamma_{\text {the }}^{\text {her }}$ he relationship between vitiviniculture and environment is much more than the recurrent image of an idyllic landscape covered in vines, evoking the converged with the agrifood system shaped by big industry, the image of this idyllic landscape is becoming ever more deconstructed. The industrial model has enabled the expansion of winemaking worldwide. Conversely, it has simultaneously generated multiple consequences, among which the environmental and social impacts stand out. This picture has increasingly thrown into question the current model of production and its parameters of quality, reflected too in the search for alternatives for wine consumption, as well as minimizing these impacts, considering the absence of agrochemical residues in the drink.

Recognition of environmental issues has led to proactive responses in various spheres, resulting in increased awareness and the implementation of actions designed to reduce the adverse impact of wine production. In the area of foodstuffs, in which vitiviniculture is included, there has been a proliferation of attempts to conserve practices linked to production and consumption that, as well as aiming to reduce environmental impacts, are considered healthier. In identifying the need to reconfigure current production methods, notions of sustainability have become critical, especially in terms of minimizing environmental and social impacts, which consequently impacts the continuation of activities developed over the course of time, as in the case of vitiviniculture. From this point of view, the sustainability of wine production cannot be conceived solely within the economic sphere, focused on the market, as has frequently occurred.

In this text, we explore the relation between vitiviniculture and environment, considering the current conjuncture in which environmental issues have gained increasing salience and recognition. We begin by discussing the development of vitiviniculture from a perspective that situates it within the broader panorama of the contemporary global agrifood system, highlighting in particular to the environmental impacts generated by this system, without ignoring the relevance of social impacts, though it is not the aim of this text to examine the latter in depth. Next, we explore 
how attempts have been made to resolve these problems through the implementation of practices rooted in notions of sustainability and, at the same time, contextualizing the extent to which Brazil has been pursuing this same direction.

\section{From VineYARD TO GLASS: THE REFINEMENT OF TECHNIQUES}

Unlike many other processed foods, wine is something extremely simple to make, given that no use of fire is necessary, sufficing for the grape skin to be broken and squashed to initiate the fermentation process, the basis of winemaking. However, the pathway between grapevine and glass includes other stages. As well as noting that particular varieties of grape are considered more suitable for wine production, those belonging to Vitis vinifera, and that specific cultivation methods are used for these vines, other processes are also included in its production: conservation/ageing, bottling, labelling, transportation, until finally the drink can be consumed.

This series of stages highlights the fact that wine is indisputably the result of human action: in other words, there is very little in its production that can be considered natural, something untouched by human hands ${ }^{4}$. This observation reminds us that wine is a cultural product and, as such, is also the outcome of the gradual employment of techniques, which have become increasingly elaborate. Over time, these techniques have enabled greater control over different stages of its production from preparing the soil, the cultivation and harvesting of the grapes, to the process of fermentation, conservation, bottling and labelling. As a consequence, it was possible to transform the drink produced locally, to be consumed in a relatively short time span, into a product that could withstand long-distance journeys and still maintain most of its properties, among them the taste of the place from which it came.

The refinement of technologies also enabled vitiviniculture to expand. Consequently, like many other foodstuffs offered for consumption in our contemporary world, side-by-side with small-scale enterprises that maintain a more

${ }^{4}$ Rachel E. Black, "Vino Naturale," in Wine and Culture, ed. Rachel E. Black and Robert C. Ulin (London/New York: Bloomsbury Publishing Plc, 2013), 279-94, https://doi.org/10.5040/9781350042254.ch-015. 
artisanal structure, wine has become a product resulting from a model of big industry, elaborated on a large scale and distributed in an increasingly global scale. However, wine production did not just increase in volume; as well as the increase in the number of producing countries, today wine is made on every continent.

Seen from a broader perspective, the development and expansion of vitiviniculture over the course of the previous century reflects the panorama of changes in agrifood systems at a global scale provoked by food modernization. Among these changes, we can highlight the period after the Second World War when, in the wake of the Green Revolution, an overall increase was seen in both the production and consumption of foods. In this context, the focus was centered on the development of techniques with the principal objective of augmenting production and overcoming food scarcity. As a result, there was a rescaling of the agrifood system, which became ever more conditioned to the use of agrochemicals.

According to Vandana Shiva, the Green Revolution, as well as posing new demands relating to scarce renewable resources and non-renewable resources, required heavy investments in fertilizers, pesticides, seeds, water and energy ${ }^{5}$. Among the consequences of this intensive agriculture were a severe ecological deterioration of lands and water resources and a reduction in crop diversity, creating new types of scarcity and vulnerability, as well as new levels of inefficiency in the use of resources. This productivist model also had impacts on vitiviniculture. Like what happened in the production of many other food items, we can point to the growing use of chemical inputs in the vineyard, such as synthetic fertilizers and pesticides, including herbicides and insecticides.

The first experiences related to the production of wines in Brazil date back to the beginning of the colonial period. It was only in the nineteenth century, however, that this production was boosted by the arrival of German and later Italian immigrants. Wine production intensified more significantly from the 1970s. From the latter decade to the present, in addition to the qualification, diversification and increase in wine production, it expanded to other areas outside the south - the main

${ }^{5}$ Vandana Shiva, The Violence of the Green Revolution: Third World Agriculture, Ecology, and Politics (Kentucky: University Press of Kentucky, 2016). 
producer region in Brazil - thereby modifying the map of vitiviniculture in the country. As examples of areas where production is rising, we can pick out the São Francisco River Valley (in the semi-arid region of the Brazilian Northeast) and the Santa Catarina Plateau ${ }^{6}$.

FAO data shows that between the start of the 1990s and the beginning of the 2000s, wine production in Brazil expanded by more than $60 \%$. Taking the state of Rio Grande do Sul as a parameter - the benchmark for vitiviniculture in the country, given that it accounts for $90 \%$ of national wine production - it was from the second half of the 1970 s that producers began to invest more substantially in technological innovation $^{8}$. Historically, innovations have always occurred in agricultural activities, including in vitiviniculture since its very beginnings ${ }^{9}$. What differentiated the 1970s from previous decades in Brazil was the intensification of technologies, whereby small wineries turned to mechanization of the production process and larger companies began to invest more widely in what, in this period, were considered 'cutting-edge technologies,' centered on the diverse processes involved in vitiviniculture ${ }^{10}$.

From a wider perspective, as wine production has expanded over recent decades, it has also reflected the situation of the global food system ${ }^{11}$. The addition of new technologies led to changes in its production and consumption, and, equally, in its forms of storage, transportation and commercialization ${ }^{12}$. The search for quality and competitiveness in wine production reflects the dynamic of the current period of globalization in which foods are mass produced at very low cost and circulate widely around the planet ${ }^{13}$. Furthermore, the investment in technologies has also made

\footnotetext{
${ }^{6}$ On the Santa Catarina production region, see: Eunice Sueli Nodari and Zephyr Frank, "Vinhos de Altitude No Estado de Santa Catarina: A Firmação de Uma Identidade," Revista Tempo e Argumento 11, no. 26 (April 24, 2019): 183-200, https://doi.org/10.5965/2175180311262019183.

${ }^{7}$ Source: FAO, "Crops Processed," Food and Agriculture Organization, 2019, http://www.fao.org/faostat/en/\#data/QD.

${ }^{8}$ For an overview of Brazilian vitiviniculture and its advances since the 1960s, see: Umberto Almeida Camargo, Jorge Tonietto, and Alexandre Hoffmann, "Progressos Na Viticultura Brasileira," Revista Brasileira de Fruticultura 33, no. spe1 (October 2011): 144-49, https://doi.org/10.1590/S0100-29452011000500017.

${ }^{9}$ For a historical perspective of wine production, see: Patrick E. McGovern, Ancient Wine: The Search for the Origins of Viniculture (Princeton and Oxford: Princeton University Press, 2003); and Rod Phillips, Uma Breve História Do Vinho (Rio de Janeiro: Record Editora, 2010).

10 José Fernando da Silva Protas and Umberto Almeida Camargo, Vitivinicultura Brasileira: Panorama Setorial de 2010 (Brasilia/Bento Gonçalves: SEBRAE/IBRAVIN: Embrapa Uva e Vinho, 2011).

11 Taking as a parameter the more recent panorama, data from the International Organization of Vine and Wine (OIV) indicate that global wine production in 2018 (excluding juices and must) was one of the highest since the year 2000, representing an increase of $17 \%$ in relation to 2017 . In South America too, data show that production rose significantly the same year, led by Argentina, Chile and Brasil. Source: Jean-Marie Aurand, "OIV 2018 Report on the World Vitivinicultural Situation," 41st World Congress of Vine and Wine, 2018, http://www.oiv.int/en/oiv-life/oiv-2018-report-onthe-world-vitivinicultural-situation.

12 lbid.

${ }^{13}$ On the globalization of the wine industry, see: Kym Anderson and Vicente Pinilla, Wine Globalization: A New Comparative History (New York:
} 
possible the cultivation of vineyards in previously unusual areas, such as the case of desert regions of Israel and China, or in arid areas of Brazil like the lower middle São Francisco river valley, the Sertão, and the Cerrado, altering the landscape of vitiviniculture in the country, as mentioned previously.

Although it has enabled the growth of vitiviniculture, this alteration in scale has also exposed a series of problems associated with wine production, especially regarding its environmental impacts. Christ and Burritt (2013) underline this point when they emphasize that cultivation of wine grapes and wine production itself are far from being environmentally benign activities ${ }^{14}$.

Given this situation, in parallel with what has been happening with other food items resulting from the current model of agriculture, predominantly productivist and predatory, wine production has also prompted re-evaluations and the search for alternatives to the existing model. In this process, notions of sustainability have come to the fore by placing on the agenda not only a reflection on the consequences of the current model of agriculture but the continuation of vitiviniculture itself. But what exactly does sustainability in vitiviniculture mean and how far has it been reflected in the Brazilian setting?

\section{Vitiviniculture AND ENVIRONMENTAL IMPACTS: NeW PERSPECtives?}

There is a common conception that, in addition to the grape variety and the vinification techniques used, a wine contains particularities of the soil and climate where the grapevine was cultivated. This principle relates to what is conventionally called the terroir ${ }^{15}$. This idea first gained traction in European countries, more

\footnotetext{
Cambridge University Press, 2018).

${ }^{14}$ Katherine L. Christ and Roger L. Burritt, "Critical Environmental Concerns in Wine Production: An Integrative Review," Journal of Cleaner Production 53 (August 2013): 232-42, https://doi.org/10.1016/j.jclepro.2013.04.007.

15 The concept of terroir originated in France and was initially linked to various French agricultural products in addition to wine. At the start of the twentieth century, however, it became predominant in the winegrowing sector, associating wines with specific properties and regions, something especially important for the controlled appellation legislation, emergent in the 1920s, which, among other objectives, sought to safeguard the notion of a regional product (Ulin, 2013). This perspective also encompasses the growing valorization of processes that emphasize the origin of products, materialized in the form of certification systems, like the Denomination of Origin (DO) and Indication of Source (IS). According to study published by the UN Food and Agriculture Organization (FAO), the specification of the place of origin of a food can improve profits and stimulate the growth of agricultural communities, potentially representing an increase in final prices of between 20 and $50 \%$, placing social, cultural and environmental issues in the center of the value chain. Source: Nações Unidas Brasil, "FAO Defende Estratégia de Comercialização de Alimentos Baseada No Lugar de Origem Dos Produtos," 2018, https://nacoesunidas.org/fao-defende-estrategia-de-comercializacao-de-alimentos-baseada-no-lugar-deorigem-dos-produtos/.
} 
specifically France whose vitiviniculture has always been strongly rooted in notions of authenticity. However, despite being contested and even generating controversies, given that modern technologies are able to compete with environmental factors, many countries around the world have based their wine production on the notion of terroir, given the renown, commercial value and distinction this can signify. This is especially the case in the current conjuncture in which wine production has converged with the mass production of goods to supply an ever more globalized market $^{16}$. On this point, we concur with Cisterna (2013) when he observes the importance of thinking of the terroir as something resulting from the intersection between physical environment, agricultural techniques, economic factors and symbolic representations.

While the environment (the climate and the quality of the air, water and soil) plays an important role in vitiviniculture, the opposite is also undeniable: wine production has progressive impacts on the physical environment. These impacts have become less and less confined to the area of the vineyard and the winery, encompassing the different stages that comprise the trajectory from the winery to the consumer. Consequently, views have emerged that question the very continuation of the agricultural production.

Christ and Burritt (2013) highlight the following as the main environmental concerns linked to the current global wine industry: the use and quality of water, the generation and management of flows of organic and inorganic residues, the use of energy and the production of greenhouse gases, the use of chemical products, questions of land use and the impact on ecosystems ${ }^{17}$. According to the same authors, these concerns may be even more specific and localized, depending on the stage of the supply chain in which they occur - in other words, in viticulture, vinification or distribution.

\footnotetext{
${ }^{16}$ On representations and discourses linked to the notion of terroir from the social, cultural, historical and political point of view, see: Sarah Daynes, "The Social Life of Terroir among Bordeaux Winemakers," in Wine and Culture, ed. Rachel E. Black and Robert C. Ulin (London/New York: Bloomsbury Publishing PIc, 2013), 15-32, https://doi.org/10.5040/9781350042254.ch-001; Marion Demossier, "Beyond Terroir: Territorial Construction, Hegemonic Discourses, and French Wine Culture," Journal of the Royal Anthropological Institute 17, no. 4 (December 2011): 685705, https://doi.org/10.1111/j.1467-9655.2011.01714.x; and Robert C. Ulin, "Terroir and Locality: An Anthropological Perspective," in Wine and Culture, ed. Rachel E. Black and Robert C. Ulin (London/New York: Bloomsbury Publishing Plc, 2013), 67-84, https://doi.org/10.5040/9781350042254.ch-004.

17 Christ and Burritt, "Critical Environmental Concerns in Wine Production: An Integrative Review."
} 
As Christ and Burritt (2013) also emphasize, wine production consumes large quantities of energy and generates a considerable quantity of greenhouse gases ${ }^{18}$. Furthermore, the distribution and logistics of the post-production of wines are also intensive sources of carbon dioxide $\left(\mathrm{CO}_{2}\right)$ emissions, in part due to the dependency on heavy and bulky forms of packaging ${ }^{19}$. In terms of environmental impacts, we also need to consider the destination of these bottles after use, the fabrication of corks, which involves the cultivation of cork oak when natural stoppers are used, the production of labels, the refrigeration of the wine, and other aspects.

An extremely important point relating to environmental issues is climate change. Food production is one of the factors directly associated with these changes. Conversely, climate change is increasingly affecting different modalities of agriculture, including grape cultivation. As global climate change becomes more intense $\mathrm{e}^{20}$, the emergence of extreme climate events like prolonged droughts are expected to become ever more common ${ }^{21}$. On this point, it is worth referring to the report of the International Organization of Wine and Vine (OIV) for the year 2017 on the global situation of vitiviniculture, pointing to a $8.2 \%$ fall in world wine production, representing one of the lowest levels in several decades ${ }^{22}$. This drop was precisely related to the occurrence of extreme climatic events, ranging from frost to drought, which affected especially the main wine-producing countries of Europe, more specifically Italy, France and Spain, while also affecting Germany ${ }^{23}$.

\footnotetext{
$18 \mathrm{lbid}$.

${ }^{19} \mathrm{~A}$ broader approach to the environmental problems linked to the global wine industry can be found in ibid.

${ }^{20}$ Especially considering the global warming evident in the last four years, which has occasioned diverse events, including hurricanes, flooding and extreme heat, specialists have warned of the urgent need to deal with climate change, since it is outpacing the efforts being made to reduce it. One example of this is the extreme heat wave that struck Europe in June 2019, representing a record temperature for the continent, an average of $2^{\circ} \mathrm{C}$ above normal. According to the World Meteorological Organization (WMO), this is a global trend that will tend to become more intense, long and frequent due to the rise in global temperatures caused by greenhouse gases, the consequences of which include impacts on the environment and human health. Source: ONU News, "OMM: Mês de Junho Foi o Mais Quente Já Registrado Na EuropaBR," 2019, https://news.un.org/pt/story/2019/07/1678802.

${ }^{21}$ Matthew Heberger, "Australia's Millennium Drought: Impacts and Responses," in The World's Water, ed. P. H. Gleick (Washington, DC: Island Press/Center for Resource Economics, 2012), 97-125, https://doi.org/10.5822/978-1-59726-228-6_5.

22 Source: Aurand, "OIV 2018 Report on the World Vitivinicultural Situation."

${ }^{23}$ On the impact of climate change on grapevine cultivation in Brazil see: Lucas da R. Garrido and Francislene Angelotti, "Impacto Potencial Das Mudanças Climáticas Sobre as Doenças Da Videira No Brasil," in Impactos Das Mudanças Climáticas Sobre Doenças de Importantes Culturas No Brasil, ed. Raquel Ghini, Emília Hamada, and Wagner Bettiol (Jaguariúna, SP: Embrapa Meio Ambiente, 2011), 331-56; On the broader changes in wine production related to smaller grape harvests caused by the instability in global climatic conditions, see: FAO, Grapes Wine (Rome, Italy: FAO (Food and Agriculture Organization of the United Nations Regional Office for Asia and the Pacific), 2009), http://www.fao.org/3/al176e/al176e.pdf.
} 
As Porto-Gonçalves (2015) reminds us, transforming an ecosystem into an agroecosystem inevitably involves losses, whether in biological diversity or the physical volumes of soils, due to their more direct exposure to solar radiation, winds and rains $^{24}$. In relation to viticulture, Rosner et al. (2015) note that when this is developed and established in certain areas for a long time, combined with the fact that the grapevines are cultivated on a permanent basis, unchecked activities in the vineyard lead to long-term problems, such as compacting of the soil, pollution of the water, or destruction of wildlife and vegetation, leading to an environmental degradation that can put at risk the very continuation of vitiviniculture, as already indicated $^{25}$.

As advances are made in our knowledge of the negative consequences of the current agrifood system - in which wine production is included - especially the disorderly used of renewable and non-renewable natural resources, air pollution, water pollution and gradual degradation of soils, and the impacts of this system on human health, whether that of rural workers or consumers, initiatives have increased around the world aiming to mitigate these impacts. These initiatives are based primarily on an agriculture in which notions of sustainability have become central, albeit still marginal when compared to the increasingly negative effects of the dominant model's environmental impacts.

Just as the environmental impacts are not limited to agriculture, notions of sustainability, as well as being advanced in various fields, are not limited to the environmental perspective. Taking Sachs's approach as a parameter (Sachs 1990, 2002), sustainability constitutes a dynamic concept that takes into consideration the growing needs of populations in a context of constant expansion and encompasses distinct aspects, ranging from the social to the economic, ecological, territorial, cultural, environmental, national political and international political dimensions ${ }^{26}$.

\footnotetext{
${ }^{24}$ Carlos Walter Porto-Gonçalves, A Globalização Da Natureza e a Natureza Da Globalização (Rio de Janeiro: Civilização Brasileira, 2015).

${ }^{25}$ Franz Gerhard Rosner et al., "Assessment of Sustainability in Austrian Wine Production," ed. Jean-Marie Aurand, BIO Web of Conferences 5 (July 1, 2015): 01022, https://doi.org/10.1051/bioconf/20150501022.

${ }^{26}$ Ignacy Sachs, "Desarrollo Sustentable, Bio-Industrialización Descentralizada y Nuevas Configuraciones Rural-Urbanas. Los Casos de India y Brasil," Pensamiento Iberoamericano 16 (1990): 235-56; Ignacy Sachs, Caminhos Para o Desenvolvimento Sustentável (Rio de Janeiro: Garamond, 2002).
} 
In terms of agriculture, Gomiero, Pimentel and Paoletti (2011) emphasize that, aside from preserving the base of natural resources, above all soil and water, sustainability in this domain should have as an objective the minimum use possible of artificial inputs from outside the agricultural system and the recuperation of disturbances caused by cultivation and harvesting and, at the same time, should be anchored as an economically and socially viable activity ${ }^{27}$. In the same line of thought, Altieri, observing that the search for more sustainable agricultural systems has been a concern of many researchers, farmers and policymakers worldwide, extols the restoration of the biodiversity of agricultural landscapes as an essential element in the development of sustainable agriculture, arguing that biodiversity, among other factors, enables agroecosystems to promote not just soil fertility but also the protection of crops and their productivity ${ }^{28}$.

In the sphere of vitiviniculture, we can observe that in 2018 , the International Organization of Vine and Wine (OIV), the entity responsible for disseminating and promoting vitiviniculture at global level and which includes Brazil as a member, listed among its recommendations to national bodies the importance of observing more sustainable principles in this activity through the indication of some basic standards. The OIV defines sustainable vitiviniculture as

...a global strategy on the scale of the grape production and processing systems, incorporating at the same time the economic sustainability of structures and territories, producing quality products, considering requirements of precision in sustainable viticulture, risks to the environment, product safety and consumer health and valuing of heritage, historical, cultural, ecological and landscape aspects. [...] Activities in the vine and wine sector are highly dependent on natural resources: solar energy, climate, water, soils and the successful integration of these elements with ecological processes $^{29}$.

Although increasing awareness of the need to take measures that minimize the environmental impacts of vitiviniculture has become more widespread globally, it

\footnotetext{
27 Tiziano Gomiero, David Pimentel, and Maurizio G. Paoletti, "Is There a Need for a More Sustainable Agriculture?," Critical Reviews in Plant Sciences 30, no. 1-2 (January 29, 2011): 6-23, https://doi.org/10.1080/07352689.2011.553515.

${ }^{28}$ Altieri also argues that diversity can be enhanced over time through crop rotations and sequences, and in space in the form of cover crops, intercropping, agroforestry, mixtures of crops and livestock, and so on. As he also observes, correct biodiversity results in pest regulation through the restoration of the natural control of insect pests and diseases and also produces an ideal recycling of nutrients and soil conservation, activating the soil biota and all the factors that lead to sustainable yields, energy conservation and lower dependence on external inputs. Miguel A. Altieri, "The Ecological Role of Biodiversity in Agroecosystems," Agriculture, Ecosystems \& Environment 74, no. 1-3 (June 1999): 19-31, https://doi.org/10.1016/S0167-8809(99)00028-6.

29 Source: Federico Castellucci, "OIV Guidelines for Sustainable Vitiviniculture: Production, Processing and Packaging of Products," 2008, http://www.oiv.int/public/medias/2089/cst-1-2008-en.pdf.
} 
can be argued that the degree of applicability of sustainable principles in this field is conditioned by the reality of each context where the practices relating to wine production are embedded ${ }^{30}$. Christ and Burritt take as an example a study conducted in vineyards in Argentina to emphasize that the practices considered ecologically sustainable in one scenario become unsustainable when applied to another environment with different geographic conditions ${ }^{31}$. Based on this same example, they argue that while governments and industrial associations can provide assistance in the development of environmental management guidelines, it is unlikely that these will be implemented at the same level among individual organizations, given the differences both in terms of organizational activities and in geographic conditions. This consideration also suggests the importance of consolidating policies aimed at sustainability in vitiviniculture to favor their implementation at diverse scales, contemplating not only large producers or big industry but also small-scale initiatives.

Many countries around the world have implemented programs to foment sustainability in vitiviniculture ${ }^{32}$. This term acquires distinct connotations in each context. Despite the initial reference to its environmental dimension ${ }^{33}$, it has currently been evoked to emphasize its economic dimension. In Brazil, data on sustainable initiatives in vitiviniculture are still scarce. However, this does not mean the inexistence of such actions in this field. Some steps have been taken in this direction, especially through the official program of Integrated Production (IP) certification, legislated in 2001, which is based on technical procedures intended to

\footnotetext{
30 Increased awareness of the environmental impacts related to vitiviniculture also stems from growing debates on the theme. An example of this is the fact that the 20th Annual Conference of the Great Wine Capitals Global Network, held in November 2019 in Bordeaux, France, dedicated one of its main panels to this issue. The panel 'Wine, Environment and Society' included debates on the following topics: "Global Environment Issues and Impact on Society," "Impact of warming climate on the wine production," and "The impact of consumers requesting wineries to produce "clean and green' wines," also including new biological and organic cultivation techniques, as well as more ecological packaging and transport logistics. Source: OIV, "Climate Change in the Spotlight of the 20th Edition of the Great Wine Capitals Annual Conferences," 2019, http://www.oiv.int/en/oivlife/climate-change-in-the-spotlight-of-the-20th-edition-of-the-great-wine-capitals-annual-conferences.

${ }^{31}$ Christ and Burritt, "Critical Environmental Concerns in Wine Production: An Integrative Review."

32 There are a large number of certification programs for sustainability, including: ISO 14001/14004, Certified Sustainable Wine of Chile, Sustainable Winegrowing New Zealand (SWNZ), Integrity \& Sustainability Certified (South Africa), Sustainable Australia Winegrowing (SAW), Bodegas de Argentina Sustainability Protocol, Certified California Sustainable Vineyard and Winery (CCSW), Sustainability in Practice (SIP California), Certified Green (California), Low Input Viticulture and Enology (LIVE - Oregon, Washington and Idaho), Leadership in Energy and Environmental Design (LEED). Source: Marcelo Copello, "Sustentabilidade No Vinho," Vinoteca, 2017, https://vejario.abril.com.br/blog/vinoteca/sustentabilidade-no-vinho/; More information concerning the particularities of some of these programs, including in relation to their general scope of sustainability (environmental only or social and economic also), can be found in Eugenio Pomarici, Riccardo Vecchio, and Fabio Verneau, "A Future of Sustainable Wine? A Reasoned Review and Discussion of Ongoing Programs around the World," Quality - Access to Success 15, no. 139 (2014): 123-28.

33 Gergely Szolnoki, "A Cross-National Comparison of Sustainability in the Wine Industry," Journal of Cleaner Production 53 (August 2013): $243-$ 51, https://doi.org/10.1016/j.jclepro.2013.03.045.
} 
improve care of the environment, labor legislation and food security ${ }^{34}$. It was only in 2018 that the Integrated Production label, until then displayed on fruit labelling, was introduced in the winemaking sector ${ }^{35}$. However, it is important to observe that Integrated Production did not succeed in reducing the use of pesticides, revealing a gap between the intention of the aforementioned public policies and the results obtained.

The incipience of certification programs committed to environmental protection and food security does not necessarily mean the absence of practices that follow these principles ${ }^{36}$. As an example, it is worth mentioning initiatives designed to promote sustainability in agriculture, like the case of the Ipê Ecological Centre, an NGO that has been working along these lines in the southern region of Brazil ${ }^{37}$. In reference to vitiviniculture, in research conducted in the region of Campanha (RS), Flores (2018) observed various sustainable initiatives in the diverse stages involved, enabling the identification of this region's potential for more sustainable actions in wine production ${ }^{38}$. Many of these actions were indeed in line with international protocols of sustainable vitiviniculture, although very often they are not identified as such by the winegrowers.

The development of sustainable practices in vitiviniculture, therefore, does not necessarily depend on a particular certification. Nonetheless, as Flores also argues, the absence of any formalization of such initiatives through programs or policies hinders their recognition and the articulation of actions, considering the

\footnotetext{
${ }^{34}$ For more information on Integrated Production in Brazil, see: MAPA, Produção Integrada No Brasil: Agropecuária Sustentável, Alimentos Seguros (Brasília: Ministério da Agricultura Pecuária e Abastecimento (MAPA), 2009), https:/www.gov.br/agricultura/ptbr/assuntos/sustentabilidade/producao-integrada/documentos-producao-integrada/producao-integrada-no-brasil.pdf/@@download/file/producaointegrada-no-brasil.pdf.

35 This introduction took place in a vineyard in the southern region of the country. See: Redação Globo Rural, "Vinícola Gaúcha é a Primeira a Receber Selo de Produção Integrada," 2018, https://revistagloborural.globo.com/Noticias/Sustentabilidade/noticia/2018/07/vinicola-gaucha-eprimeira-receber-selo-de-producao-integrada.html.

${ }^{36}$ Also in relation to certifications in Brazil, aside from the Organic certificate for wine production included in this category, it is important to recall that the growing market demands for certified quality include production that values the origin of the foods. In Brazil, some moves have been made in this direction, such as the implementation of geographical indications (Indication of Source and Denomination of Origin). The Vineyard Valley (RS) was the first DO in the country, while other regions already possess IS certificates (Pinto Bandeira/RS, Altos Montes/RS, Monte Belo/RS, Farroupilha/RS, Vinho de Uva Goethe/SC) or are in the process of being established (Vinhos da Campanha/RS and Vinhos do Vale do São Francisco/PB/BA). For information on geographical indications, see: IBRAVIN, "Indicações Geográfica," Instituto Brasileiro do Vinho (IBRAVIN), 2012, https://www.ibravin.org.br/Indicacoes-Geograficas.

${ }^{37}$ Source: Centro Ecológico, "Centro Ecológico Ipê-Serra," 2019, http://m.centroecologico.org.br.

38 Shana Sabbado Flores, "A Região Dos 'Vinhos Da Campanha' e Suas Perspectivas de Sustentabilidade," Territoires Du Vin 9 (2018), http://preo.u-bourgogne.fr/territoiresduvin/index.php?id=1639.
} 
contribution of these programs to enabling a more effective performance in this direction $^{39}$.

There is no doubt that many Brazilian consumers are becoming more aware of the environmental and human health issues related to the current agricultural model. This increased awareness has resulted in the search for alternatives for consumption, considering foods more in tune with the preservation of health and the environment, which is reflected in the growing supply of these products in supermarkets, grocery stores, specialty stores and also in the proliferation of ecological fairs around the country $^{40}$.

In relation to the supply of wines, although not particularly pronounced in Brazil compared to the number of vineyards dedicated to conventional production, there are some initiatives related to the production of organic wines, both natural and biodynamic, echoing what has been happening in other countries on a larger scale ${ }^{41}$. It is important to observe that these modalities of production do not necessarily fit entirely into what could be defined as a sustainable vitiviniculture ${ }^{42}$, since, as discussed earlier, the latter is not limited to the cultivation of the grapevine, but encompasses all its different stages. However, these modalities of production can be conceived as alternatives to the modality governed by the dynamic of big industry in

\footnotetext{
$39 \mathrm{lbid}$.

40 According to the Brazilian Institute of Consumer Protection (Instituto Brasileiro de Defesa do Consumidor: IDEC), the number of fairs of ecological produce today in Brazil alone corresponds to 896 initiatives. Source: Feiras Orgânicas, "Mapas de Feiras Orgânicas," 2019, $\mathrm{https}$ ://feirasorganicas.org.br; According to the Brazilian Association of Supermarkets (ABRAS), meanwhile, the organic sector has been growing 25\% per year. Source: ABRAS, "Com Crescimento de Cerca de 20\% Ao Ano, Setor de Orgânicos Ganha Espaço," 2019, https://www.abras.com.br/clipping.php?area=1\&clipping=69484.

${ }^{41}$ Briefly, organic wines can be defined as those whose vineyards are grown without the use of artificial chemical products - that is, synthetic pesticides, fertilizers or fungicides. However, cooper, sulfur dioxide (SO2) and plant or mineral based products can be used. It is important to remember that regulations on the production of organic wines vary, as in the case of the European Union, which allows some processes such as thermal treatments, filtration and reverse osmosis. Biodynamic wines are based on Anthroposophy, developed by the Austrian Rudolf Steiner, in the 1920s. Its methods are related to organic agriculture and, as well as observing the cycles of sun and moon, includes the use of natural preparations to help the plants develop a healthy immunological system, the use of mature to help plant growth, the use of cover plants and crop rotation to revitalize the soils, and the encouragement of polyculture and biodiversity, among other practices. Natural wine, for its part, is produced without chemical fertilizers or pesticides in the vineyard and without filtering, addition of yeast or enzymes, as well as little use of sulfur. As there are no official rules regulating natural wines, grape cultivation can involve the use of conventional methods and the wine is subsequently classified as natural because no additive is used posteriorly. A more in-depth examination of the characteristics of these three categories of wine can be found in Britt Karlsson and Per Karlsson, Biodynamic, Organic and Natural Winemaking (Edinburgh: Floris Books, 2014).

42 Gomiero, Pimentel and Paoletti emphasize that sustainable agriculture can acquire distinct meanings, varying from individual to individual, which reflects the complexity of delineating the panorama in question. In comparing sustainable agriculture with organic agriculture, for example, they explain that the former, as well as not referring to a set of prescribed practices, differs from organic farming because, in sustainable agriculture, agrochemicals (synthetic fertilizers and pesticides) may or may not play a role: that is, their use is limited to a minimum or they are not used, and conservation practices (crop rotation, integrated pest management, natural fertilization methods, minimal tillage, biological control) are fully integrated into agricultural management. Gomiero, Pimentel, and Paoletti, "Is There a Need for a More Sustainable Agriculture?"
} 
which quantity and standardization constitute the primary objectives, in detriment to other factors, like those of an environmental kind and those linked to food security ${ }^{43}$.

In the Brazilian context, this production is represented by small producers who work mostly in artisanal form, very often reviving ancestral practices and even almost extinct grape varieties, while also addressing the issue of the recuperation of local biodiversity ${ }^{44}$. However, unlike what happens with big industry, the lack of incentive for small producers, like the large tax burden imposed on them, ends up making unviable the proliferation of these initiatives, while also resulting in limitations in terms of their consumption more broadly ${ }^{45}$.

Compared to other countries, although Brazil is not a leader in terms of wine production and consumption, the need for a reconfiguration of this field forms part of a planet-wide shift, driven above all by the growing environmental issues related to vitiviniculture. Among the consequences of an increasingly predatory intervention in the environment, which also applies to the country's vitiviniculture sector, we can highlight the high use of agrochemicals in this modality of agriculture, placing in question damage both to the environment and to human health.

In order to provide an idea of how this issue has become configured in the country, we can turn to data from 2018 produced by the Brazilian Wine Institute (Ibravin), relating to agrochemicals registered for grapevine cultivation. These data show that among the 61 herbicides registered, 14 are extremely toxic; among the 49 insecticides registered, 14 are extremely toxic. and among the 159 fungicides

\footnotetext{
43 In relation to this more ecological modality of wine production, it is opportune to observe that Slow Food - a global-level NGO founded in Italy in the 1980s with the aim of promoting a conception of food in which quality is related to a form of production that above all values the product, the producer and the environment - created the category of Slow Wine for wines whose production follows many of the criteria relating to food, involving, among other values, those linked to health and sustainability. Information on Slow Wine relating to Brazil is available from at Slow Wine Brasil, "Slow Wine Brasil," 2019, https://www.facebook.com/slowwinebrasil/.

${ }^{44}$ One example of this recuperation of biodiversity is what has occurred in the southern region of Brazil, in relation to the Peverella grape, a variety introduced to Brazil by Italian immigrants in the nineteenth century, grown in the Serra Gaúcha and used mainly to produce wines. The competition with more commercial kinds of grape with greater profitability led producers to convert their vineyards to the cultivation of new varieties, abandoning this variety of grape, as well as the methods for running the Peverella vineyard. See: Slow Food, A Arca Do Gosto No Brasil - Alimentos, Conhecimentos e Histórias Do Patrimônio Gastronômico (Italy: Slow Food Editore, 2017).

${ }^{45} \mathrm{An}$ idea of the variety of this production can be obtained from a wine fair that has been taking place annually in the city of São Paulo since 2005 , Naturebas, bringing together Brazilian and foreign wine producers dedicated to the production of wines with lower impact on the environment and human health. According to data published on the event website, a substantial increase can be perceived in the number of exhibiters present. In total, 25 Brazilian producers have shown at the events. Though representing a very small number compared to the possibilities related to conventional wine production, it is interesting to observe the growth of this fair, since it also reproduces the increase in interest of this modality of wine. Taking as a reference point the last three years, it is already possible to identify this growth: in 2017, 64 exhibitors; in 2018, 104 exhibitors; in 2019, 125 exhibitors. Source: Feira Naturebas, "Feira Naturebas: Naturais, Orgânicos, Biodinâmicos e Criados Soltos," 2020, https://www.feiranaturebas.com.br.
} 
registered, 58 are extremely toxics ${ }^{46}$. It is important to mention that many of the agrochemicals widely used in Brazil have already been banned in diverse countries ${ }^{47}$. Research undertaken by Bombardi shows that among the agrochemicals used in the country's vineyards in 2019, 13 of them already prohibited in the European Union ${ }^{48}$. It should also be observed that according to data published by Brazil's Ministry of Agriculture, 474 new agrochemicals were registered in the country in 2019 alone. This figure is very high relative to the previous 14 years, situating Brazil in the position of world leader in the use of pesticides in agriculture ${ }^{49}$.

Based on what has been discussed above, it is possible to affirm that wine, though historically extolled for its social, cultural or economic dimensions, has also been extolled in the current conjuncture for its dependence on increasingly uncertain environmental conditions. As wine production has become part of the set of global environmental problems, the need for a reconfiguration of this field has become evident, more specifically aiming to generate less environmental impacts through its production and less impacts on human health through the consumption of pesticidefree wines. Although subordinate to the specificities of the local context, the reconfiguration needed in the field of vitiviniculture is broader in range since it involves, as well as another approach to production and consumption, the very continuity of vitiviniculture.

\section{FINAL CONSIDERATIONS}

In recent decades, wine production has attained a global scale. The development of specific technologies has contributed to this trend and to wine becoming more widely circulated around the world, reshaping consumer habits. This process reproduces the logic of food modernity, based on increasing industrialization

\footnotetext{
${ }^{46}$ The toxicological classification of agrochemicals is divided into 4 categories: extremely toxic, highly toxic, medium toxic or little toxic. Source: Comitê Técnico de Viticultura, "Agrotóxicos Registrados Para a Cultura Da Videira," 2018, https://www.ibravin.org.br/admin/arquivos/downloads/1530044356.pdf.

47 Glyphosate is the most commonly used agrochemical worldwide. On the use of this agrochemical in wine cultivation, see: Kara Cook, "Glyphosate in Beer and Wine," 2019, https://uspirg.org/sites/pirg/files/reports/WEB_CAP_Glyphosate-pesticide-beer-andwine_REPORT_022619.pdf.

$48 \mathrm{lbid}$.

49 Source: MAPA, "Em 2019, 94,5\% Dos Defensivos Agrícolas Registrados Foram Produtos Genéricos," Ministério da Agricultura, Pecuária e Abastecimento, 2019, https:/www.gov.br/agricultura/pt-br/assuntos/noticias/em-2019-94-5-dos-defensivos-agricolas-registrados-foram-produtosgenericos.
} 
aimed at mass production. We have seen that this panorama has contributed to the global environmental crisis, impacting especially on climate change and the loss of biodiversity. Because of this picture, the current model of food production has been increasingly put into question, occasioning the search for less harmful alternatives, especially in terms of damage to the environment and human health. Nevertheless, as noted in the text, the extent to which these practices are implemented depends on each context, principally the existence of favorable policies. Regarding the Brazilian context, it the recognition and strengthening of more sustainable initiatives in vitiviniculture can also be identified as a major challenge to be overcome, given that this perspective still privileges the economic dimension of sustainability rather than its environmental and social dimensions.

Although not a staple item like other foodstuffs, wine encompasses diverse dimensions. From the historical viewpoint, it is a drink that has not only reflected the interactions between human beings and their natural environment over time, but has also formed part of social interactions in diverse contexts. However, as Black and Ulin (2013) highlight, the fact that this drink is categorized simply as alcohol ends up obscuring its ritual, symbolic and social importance ${ }^{50}$. This argument also applies to its production and consumption, in a conjuncture in which, as environmental problems worsen, they jeopardize the very continuation of vitiviniculture.

The focus on wine reveals tensions between human beings and their natural environment ${ }^{51}$. Today, therefore, reflecting on a wine is much more than savoring its aroma, taste or look: it involves not losing sight of the fact that, although technologies have modified its different stages of production, the drink is still dependent on certain environmental conditions that have made possible its physical existence for centuries - in other words, the relation between vitiviniculture and environment is rooted in the past, but its foundations for surviving into the future depend increasingly on a more harmonious intervention of human beings with the environment from the present.

\footnotetext{
${ }^{50}$ Rachel E. Black and Robert C. Ulin, "Introduction," in Wine and Culture, ed. Rachel E. Black and Robert C. Ulin (London/New York: Bloomsbury Publishing Plc, 2013), 1-10, https://doi.org/10.5040/9781350042254.0005.

${ }^{51}$ Ibid.
} 


\section{ACKNOWLEDGEMENTS}

Carla Pires Vieira da Rocha thanks to CAPES for the Post-doctorate scholarship at the Federal University of Santa Catarina - Brazil. Eunice Nodari thanks to the National Council for Scientific and Technological Development (Conselho Nacional de Desenvolvimento Científico e Tecnológico, CNPq) for the Research Productivity fellowship (Pesquisador Pq) and for the grants received for the project: From Land to Table: an Environmental History of Vitiviniculture in the Americas

\section{REFERENCIAS}

ABRAS. "Com Crescimento de Cerca de 20\% Ao Ano, Setor de Orgânicos Ganha Espaço," 2019. https://www.abras.com.br/clipping.php?area=1\&clipping=69484.

Altieri, Miguel A. "The Ecological Role of Biodiversity in Agroecosystems." Agriculture, Ecosystems \& Environment 74, no. 1-3 (June 1999): 19-31. https://doi.org/10.1016/S0167-8809(99)00028-6.

Anderson, Kym, and Vicente Pinilla. Wine Globalization: A New Comparative History. New York: Cambridge University Press, 2018.

Aurand, Jean-Marie. "OIV 2018 Report on the World Vitivinicultural Situation." 41st World Congress of Vine and Wine, 2018. http://www.oiv.int/en/oiv-life/oiv2018-report-on-the-world-vitivinicultural-situation.

Black, Rachel E. "Vino Naturale." In Wine and Culture, edited by Rachel E. Black and Robert C. Ulin, 279-94. London/New York: Bloomsbury Publishing Plc, 2013. https://doi.org/10.5040/9781350042254.ch-015.

Black, Rachel E., and Robert C. Ulin. "Introduction." In Wine and Culture, edited by Rachel E. Black and Robert C. Ulin, 1-10. London/New York: Bloomsbury Publishing Plc, 2013. https://doi.org/10.5040/9781350042254.0005.

Camargo, Umberto Almeida, Jorge Tonietto, and Alexandre Hoffmann. "Progressos Na Viticultura Brasileira." Revista Brasileira de Fruticultura 33, no. spe1 (October 2011): 144-49. https://doi.org/10.1590/S0100-29452011000500017.

Castellucci, Federico. "OIV Guidelines for Sustainable Vitiviniculture: Production, Processing and Packaging of Products," 2008. http://www.oiv.int/public/medias/2089/cst-1-2008-en.pdf.

Centro Ecológico. "Centro Ecológico Ipê-Serra," 2019. http://m.centroecologico.org.br. 
Christ, Katherine L., and Roger L. Burritt. "Critical Environmental Concerns in Wine Production: An Integrative Review." Journal of Cleaner Production 53 (August 2013): 232-42. https://doi.org/10.1016/j.jclepro.2013.04.007.

Comitê Técnico de Viticultura. "Agrotóxicos Registrados Para a Cultura Da Videira," 2018. https://www.ibravin.org.br/admin/arquivos/downloads/1530044356.pdf.

Cook, Kara. "Glyphosate in Beer and Wine," 2019. https://uspirg.org/sites/pirg/files/reports/WEB_CAP_Glyphosate-pesticidebeer-and-wine_REPORT_022619.pdf.

Copello, Marcelo. "Sustentabilidade No Vinho." Vinoteca, 2017. https://vejario.abril.com.br/blog/vinoteca/sustentabilidade-no-vinho/.

Daynes, Sarah. "The Social Life of Terroir among Bordeaux Winemakers." In Wine and Culture, edited by Rachel E. Black and Robert C. Ulin, 15-32. London/New York: Bloomsbury Publishing Plc, 2013. https://doi.org/10.5040/9781350042254.ch001.

Demossier, Marion. "Beyond Terroir: Territorial Construction, Hegemonic Discourses, and French Wine Culture." Journal of the Royal Anthropological Institute 17, no. 4 (December 2011): 685-705. https://doi.org/10.1111/j.1467-9655.2011.01714.x.

FAO. "Crops Processed." Food and Agriculture Organization, 2019. http://www.fao.org/faostat/en/\#data/QD.

---. Grapes Wine. Rome, Italy: FAO (Food and Agriculture Organization of the United Nations Regional Office for Asia and the Pacific), 2009. http://www.fao.org/3/al176e/al176e.pdf.

Feira Naturebas. "Feira Naturebas: Naturais, Orgânicos, Biodinâmicos e Criados Soltos," 2020. https://www.feiranaturebas.com.br.

Feiras Orgânicas. "Mapas de Feiras Orgânicas," 2019. https://feirasorganicas.org.br.

Flores, Shana Sabbado. "A Região Dos 'Vinhos Da Campanha' e Suas Perspectivas de Sustentabilidade." Territoires Du Vin 9 (2018). http://preo.ubourgogne.fr/territoiresduvin/index.php?id=1639.

Garrido, Lucas da R., and Francislene Angelotti. "Impacto Potencial Das Mudanças Climáticas Sobre as Doenças Da Videira No Brasil.” In Impactos Das Mudanças Climáticas Sobre Doenças de Importantes Culturas No Brasil, edited by Raquel Ghini, Emília Hamada, and Wagner Bettiol, 331-56. Jaguariúna, SP: Embrapa Meio Ambiente, 2011.

Gomiero, Tiziano, David Pimentel, and Maurizio G. Paoletti. "Is There a Need for a More Sustainable Agriculture?" Critical Reviews in Plant Sciences 30, no. 1-2 (January 29, 2011): 6-23. https://doi.org/10.1080/07352689.2011.553515.

Heberger, Matthew. "Australia's Millennium Drought: Impacts and Responses." In The 
World's Water, edited by P. H. Gleick, 97-125. Washington, DC: Island Press/Center for Resource Economics, 2012. https://doi.org/10.5822/978-159726-228-6_5.

IBRAVIN. "Indicações Geográfica." Instituto Brasileiro do Vinho (IBRAVIN), 2012. https://www.ibravin.org.br/Indicacoes-Geograficas.

Karlsson, Britt, and Per Karlsson. Biodynamic, Organic and Natural Winemaking. Edinburgh: Floris Books, 2014.

MAPA. "Em 2019, 94,5\% Dos Defensivos Agrícolas Registrados Foram Produtos Genéricos." Ministério da Agricultura, Pecuária e Abastecimento, 2019. https://www.gov.br/agricultura/pt-br/assuntos/noticias/em-2019-94-5-dosdefensivos-agricolas-registrados-foram-produtos-genericos.

---. Produção Integrada No Brasil: Agropecuária Sustentável, Alimentos Seguros. Brasília: Ministério da Agricultura Pecuária e Abastecimento (MAPA), 2009. https://www.gov.br/agricultura/pt-br/assuntos/sustentabilidade/producaointegrada/documentos-producao-integrada/producao-integrada-nobrasil.pdf/@@download/file/producao-integrada-no-brasil.pdf.

McGovern, Patrick E. Ancient Wine: The Search for the Origins of Viniculture. Princeton and Oxford: Princeton University Press, 2003.

Nações Unidas Brasil. "FAO Defende Estratégia de Comercialização de Alimentos Baseada No Lugar de Origem Dos Produtos," 2018. https://nacoesunidas.org/fao-defende-estrategia-de-comercializacao-dealimentos-baseada-no-lugar-de-origem-dos-produtos/.

Nodari, Eunice Sueli, and Zephyr Frank. "Vinhos de Altitude No Estado de Santa Catarina: A Firmação de Uma Identidade." Revista Tempo e Argumento 11, no. 26 (April 24, 2019): 183-200. https://doi.org/10.5965/2175180311262019183.

OIV. "Climate Change in the Spotlight of the 20th Edition of the Great Wine Capitals Annual Conferences," 2019. http://www.oiv.int/en/oiv-life/climate-change-inthe-spotlight-of-the-20th-edition-of-the-great-wine-capitals-annualconferences.

ONU News. "OMM: Mês de Junho Foi o Mais Quente Já Registrado Na EuropaBR," 2019. https://news.un.org/pt/story/2019/07/1678802.

Phillips, Rod. Uma Breve História Do Vinho. Rio de Janeiro: Record Editora, 2010.

Pomarici, Eugenio, Riccardo Vecchio, and Fabio Verneau. "A Future of Sustainable Wine? A Reasoned Review and Discussion of Ongoing Programs around the World." Quality - Access to Success 15, no. 139 (2014): 123-28.

Porto-Gonçalves, Carlos Walter. A Globalização Da Natureza e a Natureza Da Globalização. Rio de Janeiro: Civilização Brasileira, 2015. 
Protas, José Fernando da Silva, and Umberto Almeida Camargo. Vitivinicultura Brasileira: Panorama Setorial de 2010. Brasília/Bento Gonçalves:

SEBRAE/IBRAVIN: Embrapa Uva e Vinho, 2011.

Redação Globo Rural. "Vinícola Gaúcha é a Primeira a Receber Selo de Produção Integrada," 2018.

https://revistagloborural.globo.com/Noticias/Sustentabilidade/noticia/2018/0 7/vinicola-gaucha-e-primeira-receber-selo-de-producao-integrada.html.

Rosner, Franz Gerhard, Wolfgang Dobritzhofer, Alois Geyrhofer, Josef Glatt, Stefan Großauer, Siegfried Pöchtrager, Ferdinand Regner, et al. "Assessment of Sustainability in Austrian Wine Production." Edited by Jean-Marie Aurand. BIO Web of Conferences 5 (July 1, 2015): 01022. https://doi.org/10.1051/bioconf/20150501022.

Sachs, Ignacy. Caminhos Para o Desenvolvimento Sustentável. Rio de Janeiro: Garamond, 2002.

---. "Desarrollo Sustentable, Bio-Industrialización Descentralizada y Nuevas Configuraciones Rural-Urbanas. Los Casos de India y Brasil." Pensamiento Iberoamericano 16 (1990): 235-56.

Shiva, Vandana. The Violence of the Green Revolution: Third World Agriculture, Ecology, and Politics. Kentucky: University Press of Kentucky, 2016.

Slow Food. A Arca Do Gosto No Brasil - Alimentos, Conhecimentos e Histórias Do Patrimônio Gastronômico. Italy: Slow Food Editore, 2017.

Slow Wine Brasil. "Slow Wine Brasil," 2019. https://www.facebook.com/slowwinebrasil/.

Szolnoki, Gergely. "A Cross-National Comparison of Sustainability in the Wine Industry." Journal of Cleaner Production 53 (August 2013): 243-51. https://doi.org/10.1016/j.jclepro.2013.03.045.

Ulin, Robert C. "Terroir and Locality: An Anthropological Perspective." In Wine and Culture, edited by Rachel E. Black and Robert C. Ulin, 67-84. London/New York: Bloomsbury Publishing Plc, 2013. https://doi.org/10.5040/9781350042254.ch004. 


\title{
Vinificación, Impactos Ambientales y Sostenibilidad: Nuevas Vías desde el Viñedo al Vaso?
}

\begin{abstract}
RESUMEN
En este texto exploramos la relación entre vitivinicultura y medio ambiente, observando la coyuntura actual en la que los problemas ambientales están empeorando. Tomando como referencia una base historiográfica y como marco de tiempo desde la década de 1970 hasta el presente, comenzamos por examinar el desarrollo de la vitivinicultura desde la perspectiva más amplia del sistema agroalimentario mundial contemporáneo, destacando en particular los impactos ambientales generados por este sistema. A continuación, teniendo en cuenta el panorama de la vitivinicultura en Brasil, nos centramos en las nociones de sostenibilidad con el objetivo de delinear las posibilidades de reconfiguración de este problema y, al mismo tiempo, contextualizar el grado en que país ha estado siguiendo esta dirección. Concluimos que el futuro de la vinificación depende especialmente de una intervención más armónica de los seres humanos en el medio ambiente
\end{abstract}

Palabras Clave: Vinificación; Sistema Agroalimentario Global; Sustentabilidad; Vitivinicultura.

Recibido: 20/01/2020

Aprobado: 26/03/2020 